\title{
High dose of urea enhances the nickel and copper toxicity in Brazilian elodea (Egeria densa Planch. Casp.)
}

\author{
Maria Maleva $^{1}$ - Galina Borisova ${ }^{1}$ Nadezhda Chukina ${ }^{1} \cdot$ Adarsh Kumar $^{1}$ • \\ Majeti Narasimha Vara Prasad ${ }^{2}$
}

Received: 11 February 2016/Accepted: 10 May 2016/Published online: 26 May 2016

(C) Botanical Society of Sao Paulo 2016

\begin{abstract}
Selected cellular responses for urea $(5 \mathrm{mM}), \mathrm{Ni}$ $(100 \mu \mathrm{M})$, and $\mathrm{Cu}(100 \mu \mathrm{M})$ treatments and their combined effects on the leaves of a submerged macrophyte Brazilian elodea (Egeria densa Planch. Casp.) were studied for 4 days. It was observed that the high dose of urea $(5 \mathrm{mM})$ had a significant toxic effect on some physiological and biochemical characteristics of $E$. densa such as the content of chlorophyll $a$ and the activities of catalase, ascorbate peroxidase, and guaiacol peroxidase. The elevated level of lipid peroxidation was accompanied by the accumulation of proline and ascorbate. A substantial increase in the amount of proline and urease activity was observed in Urea + Ni-treated leaves. The ascorbate content significantly increased in all the treated plants which correlated with ascorbate peroxidase activity. Urea with $\mathrm{Cu}$ ions affected the E. densa photosynthetic pigment system and urease activity adversely. The catalase activity was inhibited by the action of all the pollutants studied, especially in Urea $+\mathrm{Cu}$-treated plants, whereas the peroxidases activity (APX and GPX) increased under the $\mathrm{Cu}$ and Urea $+\mathrm{Cu}$ action. The results presented indicate that the addition of the high dose of urea $(5 \mathrm{mM})$ to the heavy metals studied
\end{abstract}

Electronic supplementary material The online version of this article (doi:10.1007/s40415-016-0290-y) contains supplementary material, which is available to authorized users.

Adarsh Kumar

adarsh.biorem@gmail.com

1 Department of Plant Physiology and Biochemistry, Faculty of Biology, Institute of Natural Sciences, Ural Federal University named after the first President of Russia B. N. Yeltsin, Mira str., 19, Ekaterinburg, Russia 620002

2 Department of Plant Sciences, University of Hyderabad, Hyderabad 500046, Telangana, India may enhance the toxic effects in E. densa leaves, especially in the case of copper.

Keywords Heavy metals - Oxidative stress . Photosynthetic pigments - Pro- and antioxidant reactions . Urease

\section{Introduction}

In natural ecosystems, plants are exposed to a complex action of organic and inorganic pollutants. They can have both synergistic and antagonistic effects on various physiological and biochemical parameters of plants (Chukina and Borisova 2010; Maleva et al. 2012). Heavy metals (HMs) are the most common pollutants in various parts of the world (Yadav 2010). Nickel (Ni) and copper $(\mathrm{Cu})$ are essential micronutrients for the growth and development of higher plants. Being an integral constituent of enzymes, they are involved in a wide range of biochemical and physiological processes. $\mathrm{Ni}$ is the component of metalloenzyme urease, which hydrolyses urea to ammonia and carbon dioxide (Witte 2011). It also activates other enzymes including nitrate reductase and has a stabilizing effect on the ribosome structure of plants (Polacco et al. 2013). However, the excessive concentration of Ni results in phytotoxicity. The increase in $\mathrm{Ni}$ concentration (up $50 \mu \mathrm{M}$ ) induces the sublethal oxidative stress in Elodea canadensis Michx. leaves after 5 days of exposure. In addition, it results in the gradual decrease in the photosynthetic function and respiration rate (Maleva et al. 2009). As a non-redox-active metal, Ni cannot generate free radicals directly; however, it can indirectly trigger oxidative stress by destroying the balance of production and scavenging reactive oxygen species (ROS), such as hydrogen 
peroxide, hydroxyl and superoxide radicals, and single oxygen (Yilmaz and Parlak 2011). Copper plays an essential role in many enzyme systems but causes toxicity at higher concentration (Haifang et al. 2016). This metal with its variable valency can directly participate in the production of highly toxic hydroxyl radicals during the Fenton and Haber-Weiss reactions, activating the chain reaction of lipid peroxidation, which leads to oxidative stress and the damage of cell membranes (Maksymiec 1997).

The HMs toxicity has also become one of the important factors responsible for the limited plant growth under natural conditions (Upadhyay 2014). The elevated concentrations of nitrogen compounds are also detected in water bodies of the urbanized territories causing deleterious effect on plant growth. Urea (carbamide) is one of the widespread organic pollutants which is characterized by its unique physiochemical properties: non-polarity, high solubility, rapid absorption and low phytotoxicity. Due to these properties, urea is considered a more effective fertilizer than nitrates and ammonium. However, the widespread use of urea in farming is one of the major sources of ammonia in aquatic ecosystem. The trend towards the global urea use is expected to continue, and thus, the pollution of coastal waters around the world will tend to increase (Glibert et al. 2006; Azizullah et al. 2011).

Urea can be produced by various organisms as a product of linking ammonia during the dissimilation of proteins and the decomposition of dead organisms (Witte 2011). There are sufficient data about urea's indirect and long-term adverse effects on the ecosystems (Finay et al. 2010). Urea in high concentration causes physiological disorder in plants including reduced productivity and proteins' denaturation (Mokronosov et al. 1966; Krogmeier et al. 1989). Our previous data reported that high doses of urea (more than $100 \mathrm{mg} \mathrm{L}^{-1}$ ) can decrease the photosynthetic function and induce oxidative stress in Elodea densa (Planch.) Casp. leaves (Maleva et al. 2013, 2015).

To minimize the harmful effects of ROS, plants have evolved an effective defense system which includes low molecular weight antioxidants (proline, ascorbic acid, gluthation, etc.) and antioxidant enzymes (Yadav 2010). Ascorbic acid, the essential compound of plant cells, reacts directly with superoxide, singlet oxygen and indirectly with hydrogen peroxide through ascorbate peroxidase (Nakano and Asada 1981). Proline is a compatible osmolyte and is known to accumulate in response to various kinds of abiotic stress and is therefore accepted as an indicator of environmental stress (Alia-Saradhi 1991; Szabados and Savouré 2010). Catalase and peroxidases play a key role in controlling the level of hydrogen peroxide, and numerous stress factors were reported to stimulate these enzymes (Teisseire and Guy 2000). However, the effects of different types of pollutants on the activities of these enzymes remain controversial (Teisseire and Guy 2000; Maleva et al. 2015).

In aquatic ecosystems, plants are exposed to a complex of pollutants. Due to excessive application, urea may be washed off from the agricultural fields and mix with heavy metal-loaded water bodies, and can cause severe adverse effects on aquatic ecosystem. At the same time, the study of the combined effect of different pollutants is quite difficult in natural habitats.

Previously, in the model experiments, it was shown that urea could antagonize the negative effect of herbicide (fenoxaprop-P-ethyl) at concentration 1-4 $\mathrm{g} \mathrm{L}^{-1}$, while the high urea concentration $\left(8 \mathrm{~g} \mathrm{~L}^{-1}\right)$ aggravated this effect in Perilla frutescens (L.) Britt. (Zhang et al. 2014). However, the combined effect of urea and HMs is practically not studied. Therefore, the aim of this research is to evaluate the short-term effect of urea, $\mathrm{Ni}$ and $\mathrm{Cu}$ (acting separately and combined) on the photosynthetic pigment system, lipid peroxidation, content of low molecular weight antioxidants (proline and ascorbate) and enzyme activities (urease, catalase, ascorbate peroxidase and guaiacol peroxidase) in E. densa leaves.

\section{Materials and methods}

\section{Plant material and experimental design}

Experiments were performed with an aquatic plant from the Hydrocharitaceae family: Egeria densa (syn. Elodea densa (Planch.) Casp. or Brazilian elodea). It is one of the most popular aquarium and pond species, naturally growing in deep, stagnant or slow-moving water bodies and found widely distributed in parts of Brazil, Uruguay and Argentina. This submerged aquatic macrophyte is undemanding in cultivation under laboratory conditions; the plants grow without rooting and rapidly produce the biomass.

Shoots of E. densa (12-15 cm in length, 15 samples per tank) previously grown in the aquarium culture were incubated for 4 days in a culture medium (Uniflor aqua 7; OOO "ZOOMIR", Russia, containing $3.2 \mathrm{mg} \mathrm{L}^{-1} \mathrm{~K}$; $1.9 \mathrm{mg} \mathrm{L} \mathrm{L}^{-1} \mathrm{~N} ; \quad 0.2 \mathrm{mg} \quad \mathrm{L}^{-1} \quad \mathrm{P} ; \quad 0.02 \mathrm{mg} \mathrm{L}^{-1} \quad \mathrm{Fe}$; $\left.0.005 \mathrm{mg} \mathrm{L}^{-1} \mathrm{Mn}\right)$ at $23-25{ }^{\circ} \mathrm{C}$ under natural illumination $\left(100-150 \mu \mathrm{M} \mathrm{m}^{-2} \mathrm{~s}^{-1}\right)$ and photoperiod (10:14). Urea $(5 \mathrm{mM}), \mathrm{Ni}(100 \mu \mathrm{M})$, Urea $+\mathrm{Ni}(5 \mathrm{mM}+100 \mu \mathrm{M}), \mathrm{Cu}$ $(100 \mu \mathrm{M})$ and Urea $+\mathrm{Cu}(5 \mathrm{mM}+100 \mu \mathrm{M})$ were added in the experimental tanks $(3.0 \mathrm{~L})$, while plants without pollutant treatment were used as a control. All metal ions were added in sulphate form. The concentration of urea and HMs was chosen by experimental trials (Maleva et al. 2012, 2013). The experimental solutions in all the 
treatments were refreshed daily to ensure constant concentrations of the pollutants. After incubation, shoots were thoroughly washed with $0.01 \%$ ethylene diamine tetraacetic acid disodium solution $\left(\mathrm{Na}_{2}\right.$ EDTA) and twice with distilled water. Fresh leaves were separated and used for future analysis.

\section{Photosynthetic pigment assay}

Photosynthetic pigments were extracted from leaves in cooled ethanol $(96 \%)$ in dark. After centrifugation at $8000 \mathrm{~g}$ for $10 \mathrm{~min}$, the absorbance was measured using UV-Visible spectrophotometer (PD303UV Medical and Analytical Equipment from Apel, Japan) at wavelengths of 470, 649 and $664 \mathrm{~nm}$. The photosynthetic pigment content in the leaf samples was calculated according to Lichtenthaler (1987).

\section{Determination of lipid peroxidation}

Lipid peroxidation was estimated by measuring the total amount of thiobarbituric acid (TBA) reactive products, as described by Health and Packer (1968). Fresh leaves $(0.5 \mathrm{~g})$ were homogenized in $4 \mathrm{~mL}$ of the reaction medium containing $0.25 \%$ TBA in $10 \%$ trichloroacetic acid (TCA). Then the extract was heated at $95{ }^{\circ} \mathrm{C}$ for $30 \mathrm{~min}$ and rapidly cooled in ice. After centrifugation at $12,000 \mathrm{~g}$ for $10 \mathrm{~min}$, the absorbance was measured at $532 \mathrm{~nm}$ and corrected for non-specific turbidity by subtracting the absorbance at $600 \mathrm{~nm}$. The concentration of TBA-reactive products was calculated using the extinction coefficient of $155 \mathrm{mM}^{-1} \mathrm{~cm}^{-1}$ and expressed in $\mu \mathrm{M}$ MDA (malondialdehyde) $\mathrm{g}^{-1}$ of dry weight (DW).

\section{Determination of low molecular weight antioxidants}

Proline content was determined by the standard method (Bates 1973) modified by Kalinkina et al. (1990) using acidic ninhydrin reagent. The water extracts of fresh leaves (200 $\mathrm{mg}$ on $10 \mathrm{~mL}$ ) were placed in the tubes and incubated at $100{ }^{\circ} \mathrm{C}$ for $10 \mathrm{~min}$. The reaction medium containing the prepared extract $(1 \mathrm{~mL})$, glacial acetic acid $(1 \mathrm{~mL})$ and ninhydrin reagent $(1 \mathrm{~mL})$ was placed in a boiling water bath for $1 \mathrm{~h}$ and then cooled in ice rapidly. The proline standard curve was made following the same protocol. The proline content was quantified spectrophotometrically at $520 \mathrm{~nm}$ and expressed in $\mu \mathrm{M} \mathrm{g}^{-1} \mathrm{DW}$.

Ascorbic acid was estimated by measuring its oxidation with the decrease in absorbance at $265 \mathrm{~nm}$ (Hewitt and Dickes 1961). Fresh leaves $(0.3 \mathrm{~g})$ were homogenized in $3 \mathrm{~mL} 2 \%$ (w/v) metaphosphoric acid at $20^{\circ} \mathrm{C}$. The homogenate was transferred to a $10-\mathrm{mL}$ flask, and the volume was made up with $2 \%$ (w/v) metaphosphoric acid:
0.21 M trisodium phosphate $(3: 2, \mathrm{v} / \mathrm{v}), \mathrm{pH}$ 7.3-7.4. The extract was centrifuged for $3 \mathrm{~min}$ at $4000 \mathrm{~g}\left(20^{\circ} \mathrm{C}\right)$, and the absorbance was measured at $265 \mathrm{~nm}$ against a blank containing the metaphosphoric acid-trisodium phosphate mixture. Ascorbate content was calculated using the extinction coefficient of $1.65510^{4} \mathrm{mM}^{-1} \mathrm{~cm}^{-1}$ and expressed in $\mu \mathrm{M} \mathrm{g}^{-1} \mathrm{DW}$.

\section{Determination of soluble protein}

The soluble protein concentration was determined according to Bradford (1976), using bovine serum albumin (Sigma-Aldrich, USA) as a standard.

\section{Enzyme assays}

For the determination of enzymes activity, the samples of fresh leaves $(0.5 \mathrm{~g})$ were placed into a cool $\left(2-4{ }^{\circ} \mathrm{C}\right) 0.1 \mathrm{M}$ sodium phosphate buffer (pH 7.4) containing $1 \mathrm{mM} \mathrm{Na}-$ EDTA and $2 \%$ PVP and homogenized on ice. The homogenate was centrifuged for $20 \mathrm{~min}$ at $15,000 \mathrm{~g}$ at $4{ }^{\circ} \mathrm{C}$, and supernatant was collected for enzyme measurements.

Urease (EC 3.5.1.5) activity was estimated according to the method of Jayaraman (1981). It is based on the spectrophotometric determination of the Nessler's reagent and ammonia nitrogen coloured complex at $405 \mathrm{~nm}$. The amount of ammonia liberated in the test solution was calculated by calibrating the reagent with standard ammonium chloride solution. The urease activity was expressed in $\mu \mathrm{M}$ $\mathrm{NH}_{3} \mathrm{mg}^{-1}$ protein $\min ^{-1}$.

Catalase (CAT, EC 1.11.1.6) activity was determined by measuring the decomposition of hydrogen peroxide $\left(\mathrm{H}_{2} \mathrm{O}_{2}\right)$ in time at $240 \mathrm{~nm}$ and $30{ }^{\circ} \mathrm{C}$ according to the modified method of Aebi (1971). The reaction mixture $(3 \mathrm{~mL})$ contained $0.1 \mathrm{M}$ sodium phosphate buffer ( $\mathrm{pH}$ 7.0), $2 \mathrm{mM}$ $\mathrm{H}_{2} \mathrm{O}_{2}$ and $0.2 \mathrm{~mL}$ of the enzyme extract. The enzyme activity was calculated using the extinction coefficient of $0.036 \mathrm{mM}^{-1} \mathrm{~cm}^{-1}$ and expressed in $\mathrm{mM}$ of $\mathrm{H}_{2} \mathrm{O}_{2} \mathrm{mg}^{-1}$ protein $\mathrm{min}^{-1}$. Ascorbate peroxidase (APX, EC 1.11.1.11) activity was measured according to Nakano and Asada (1981). Briefly, the reaction mixture contained $50 \mathrm{mM}$ sodium phosphate buffer ( $\mathrm{pH} 7.0$ ), $0.5 \mathrm{mM}$ L-ascorbate, $0.1 \mathrm{mM} \mathrm{H} \mathrm{H}_{2} \mathrm{O}_{2}, 0.1 \mathrm{mM}$ Na-EDTA and $0.4 \mathrm{~mL}$ of the enzyme extract. The reaction started after the $\mathrm{H}_{2} \mathrm{O}_{2}$ addition, and the absorbance was measured at $290 \mathrm{~nm}$ and $30{ }^{\circ} \mathrm{C}$. The APX activity was measured using the extinction coefficient of $2.8 \mathrm{mM}^{-1} \mathrm{~cm}^{-1}$ and expressed in $\mathrm{mM}$ of ascorbate $\mathrm{mg}^{-1}$ protein $\mathrm{min}^{-1}$. Guaiacol peroxidase (GPX, EC 1.11.1.7) activity was assayed according to Chance and Maehly (1955) by the increase in the optic density of reaction medium for $1 \mathrm{~min}$ at $470 \mathrm{~nm}$ and $30{ }^{\circ} \mathrm{C}$ as a result of guaiacol oxidation. The reaction mixture $(3 \mathrm{~mL})$ 
contained $0.1 \mathrm{M}$ sodium phosphate buffer ( $\mathrm{pH}$ 7.0), $0.05 \mathrm{~mL}$ of $33 \% \mathrm{H}_{2} \mathrm{O}_{2}, 0.05 \mathrm{~mL}$ of guaiacol and $0.04 \mathrm{~mL}$ of the supernatant. The activity was expressed in $\mathrm{mM}$ of tetraguaiacol $\mathrm{mg}^{-1}$ protein $\mathrm{min}^{-1}$ using the extinction coefficient of $26.6 \mathrm{mM}^{-1} \mathrm{~cm}^{-1}$.

\section{Data analysis}

Data are presented as mean values \pm standard error (SE) for three independent experiments, each with three replicates. Different letters represent significantly different values according to Mann-Whitney $U$ test at $P<0.05$ level of significance (Statistica 6.0).

\section{Results}

\section{Effect on photosynthetic pigment content}

No significant effect was observed on chlorophyll $b(\mathrm{Chl} b)$ and carotenoid (CAR) amount; however, the decrease in

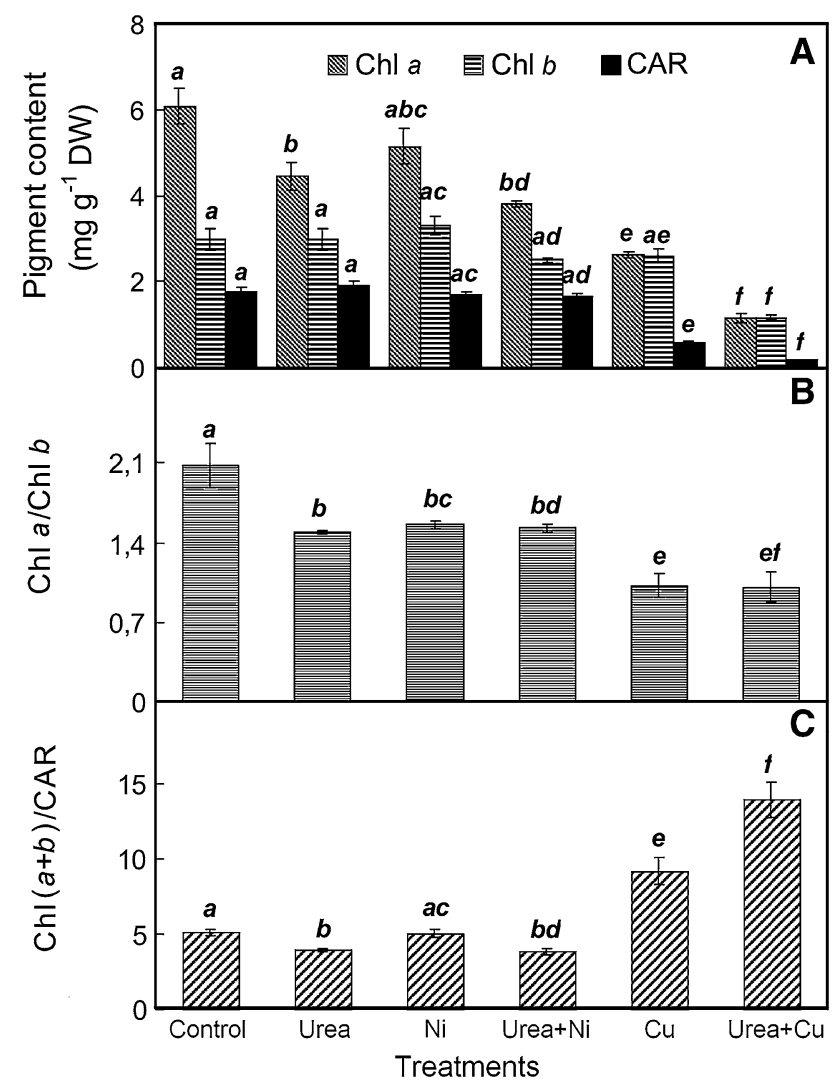

Fig. 1 Effect of urea, nickel and copper (separately and combined) on the chlorophyll $a$ (Chl $a$ ), chlorophyll $b(\mathrm{Chl} b)$, carotenoids (CAR) content (A); ratio chlorophyll $a /$ chlorophyll $b$ (B) and ratio chlorophyll $(a+b)$ /carotenoids (C) in Egeria densa leaves. Mean values $\pm \mathrm{SE}, n=3$. Different letters present significantly different values according to Mann-Whitney $U$ test, $P<0.05$ (a = control) chlorophyll $a(\mathrm{Chl} a)$ content was found in Brazilian elodea leaves (Fig. 1a). The addition of $\mathrm{Ni}$ ions to the culture medium did not act on the pigment content; however, a significant decrease in Chl $a$ amount was observed in Urea $+\mathrm{Ni}$-treated plants. The $\mathrm{Cu}$ treatment significantly reduced the content of $\mathrm{Chl} a$ and carotenoids (by 57 and $67 \%$ compared to the control, respectively), while the content of $\mathrm{Chl} b$ decreased to a lesser extent. The adverse effect of $\mathrm{Cu}$ increased in the presence of urea: a considerable decrease in Chl $a$ (by $80 \%$ ), Chl $b$ (by $60 \%$ ) and almost complete degradation of carotenoids (by $90 \%$ ) in comparison with control was observed (Fig. 1a). The ratio of Chl $a$ to $\mathrm{Chl} b$ in the treated leaves of $E$. densa decreased, especially during $\mathrm{Cu}$ and combined Urea $+\mathrm{Cu}$ treatment (Fig. 1b). The ratio of total chlorophyll (Chl $(a+b))$ to carotenoids in urea- and $\mathrm{Ni}$ (separately and combined)-treated plants was almost unchanged (Fig. 1c). However, it increased in $\mathrm{Cu}$ and Urea $+\mathrm{Cu}$-treated plants (1.7 and 2.7 times, respectively).

\section{Effect on MDA content}

The total amount of MDA increased 1.5-1.7 times as compared to the control during the urea, $\mathrm{Ni}$ and its combined treatment of Brazilian elodea plants (Table 1). However, the significant decrease in the MDA content (an average of 1.6 times) was found for $\mathrm{Cu}$ and Urea $+\mathrm{Cu}$.

\section{Effect on low molecular weight antioxidant contents}

A substantial increase in the amount of proline was detected in urea (by $50 \%$ )- and Urea $+\mathrm{Ni}$ (by $30 \%$ )treated plants as compared to the control. Separately, Ni had no considerable effect on the content of proline. The combined effect of urea and $\mathrm{Cu}$ caused a significant decrease in the proline content (ca 3.0 times). Almost complete proline degradation (by $87 \%$ of control) occurred in Cu-treated plants (Table 1). The content of ascorbic acid was increased under the action of all the pollutants studied (Table 1). The considerable increase was observed under $\mathrm{Cu}$ treatment and Urea $+\mathrm{Cu}$ treatment (ca 1.6 and 2.2 times, respectively).

\section{Effect on soluble protein content}

The content of soluble protein was significantly reduced in $\mathrm{Ni}$ - and Urea + Ni-treated plants (by 15 and $20 \%$ of the control, respectively). The effect of $\mathrm{Cu}$ and Urea $+\mathrm{Cu}$ caused a substantial decrease in the soluble protein content in E. densa leaves (ca 70 and $90 \%$ of the control, Table 1). 
Table 1 Effect of urea, nickel and copper (separately and combined) on the content of TBA-reactive products (MDA), proline, ascorbate and soluble protein in Egeria densa leaves

\begin{tabular}{lcllr}
\hline Treatments & $\begin{array}{l}\text { MDA } \\
\left(\mu \mathrm{M} \mathrm{g}^{-1} \mathrm{DW}\right)\end{array}$ & $\begin{array}{l}\text { Proline } \\
\left(\mu \mathrm{M} \mathrm{g}^{-1} \mathrm{DW}\right)\end{array}$ & $\begin{array}{l}\text { Ascorbate } \\
\left(\mu \mathrm{M} \mathrm{g}^{-1} \mathrm{DW}\right)\end{array}$ & $\begin{array}{l}\text { Soluble protein } \\
\left(\mathrm{mg} \mathrm{g}^{-1} \mathrm{DW}\right)\end{array}$ \\
\hline Control & $5.86 \pm 0.29 \mathrm{a}$ & $5.57 \pm 0.56 \mathrm{a}$ & $17.28 \pm 0.57 \mathrm{a}$ & $104.99 \pm 1.20 \mathrm{a}$ \\
Urea & $8.65 \pm 0.43 \mathrm{~b}$ & $8.30 \pm 0.28 \mathrm{~b}$ & $20.18 \pm 0.64 \mathrm{~b}$ & $111.89 \pm 0.43 \mathrm{~b}$ \\
$\mathrm{Ni}$ & $10.27 \pm 0.51 \mathrm{c}$ & $5.65 \pm 0.43 \mathrm{ac}$ & $24.18 \pm 0.81 \mathrm{c}$ & $89.20 \pm 0.90 \mathrm{c}$ \\
Urea $+\mathrm{Ni}$ & $9.42 \pm 0.47 \mathrm{~d}$ & $7.18 \pm 0.20 \mathrm{~d}$ & $20.67 \pm 0.75 \mathrm{bd}$ & $84.00 \pm 0.50 \mathrm{~d}$ \\
$\mathrm{Cu}$ & $3.68 \pm 0.18 \mathrm{e}$ & $0.73 \pm 0.06 \mathrm{e}$ & $37.58 \pm 0.94 \mathrm{e}$ & $28.85 \pm 0.75 \mathrm{e}$ \\
Urea $+\mathrm{Cu}$ & $3.48 \pm 0.17 \mathrm{f}$ & $1.76 \pm 0.12 \mathrm{f}$ & $26.99 \pm 1.55 \mathrm{f}$ & $10.61 \pm 0.17 \mathrm{f}$ \\
\hline
\end{tabular}

Mean values \pm SE, $n=3$. Different letters present significantly different values according to MannWhitney $U$ test, $P<0.05$ (a = control)
Fig. 2 Effect of urea, nickel and copper (separately and combined) on the urease $(A)$; catalase $(B)$; ascorbate peroxidase $(C)$ and guaiacol peroxidase $(D)$ activity in Egeria densa leaves. Mean values $\pm \mathrm{SE}, n=3$. Different letters present significantly different values according to Mann-Whitney $U$ test, $P<0.05$ $(\mathrm{a}=$ control $)$

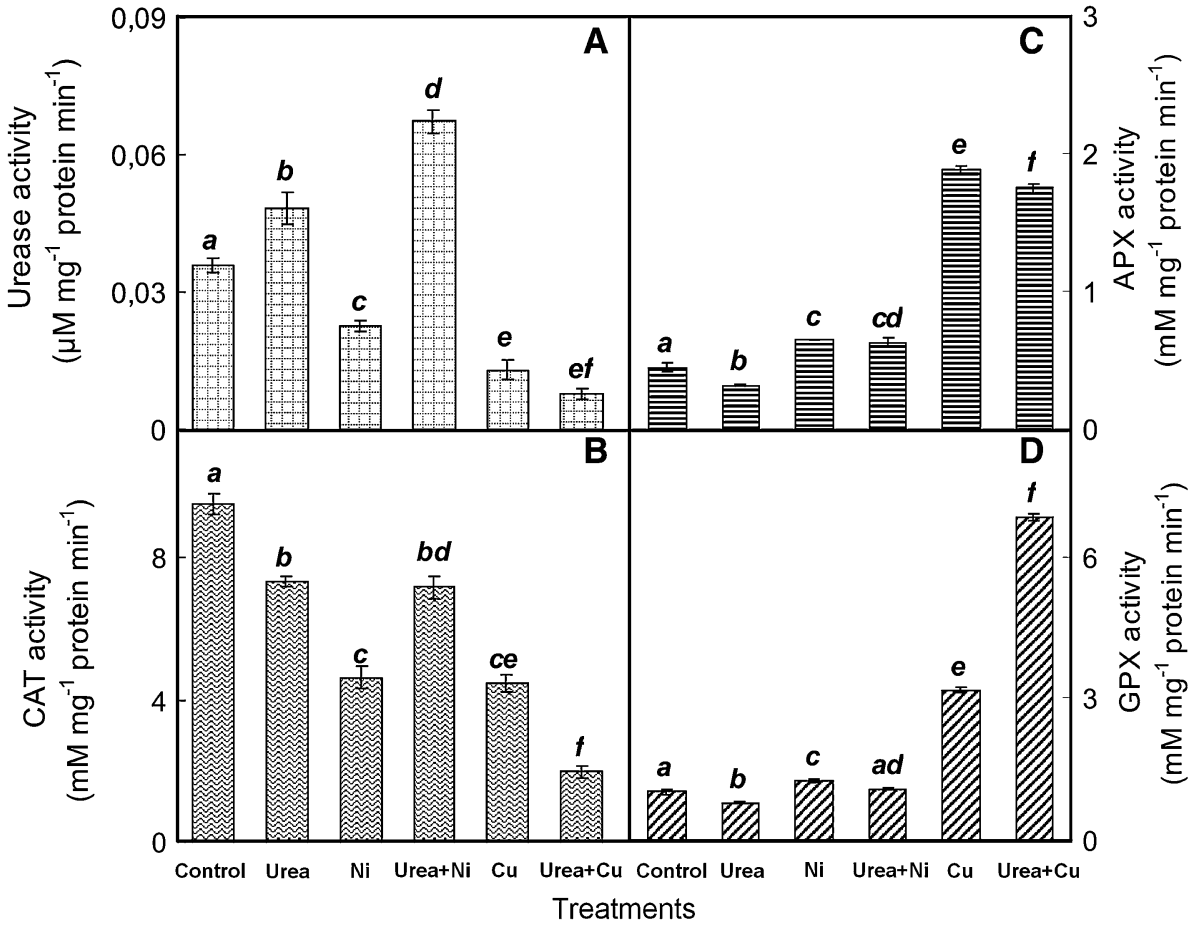

\section{Effect on enzymes activity}

A significant increase in the urease activity of urea-treated plants (by $35 \%$ ) and under the combined action of urea and $\mathrm{Ni}$ (about 2 times of the control) was observed (Fig. 2a). However, the addition of $\mathrm{Ni}$ ions to the medium inhibited the activity of urease by $37 \%$ (Fig. 2a). In the presence of $\mathrm{Cu}$, the urease activity decreased by more than 2 times under its single action and 3 times under the combined action with urea.

Catalase activity was inhibited by the action of all the pollutants studied (Fig. 2b). The largest decline in CAT activity (in 3 times) was observed in Urea + Cu-treated plants. Urea treatment significantly reduced the activity of peroxidases (APX and GPX, Fig. 2c, d). At the same time, $\mathrm{Cu}$ and $\mathrm{Urea}+\mathrm{Cu}$ treatment caused a substantial increase in the peroxidase activity ( 3.5 and 5.3 times, respectively). The activity of the APX showed a good correlation with the ascorbate content in $E$. densa leaves (the coefficient of Spearman rank correlation 0.83, $n=12, P<0.05$ ).

\section{Discussion}

This study was performed to analyse the effect of urea at high concentrations, which exceeded the maximum allowable concentration for water bodies of fishery importance by 3.75 times (Federal Fisheries Agency 2010). Since aquatic macrophytes in the natural habitats are exposed to the complex action of organic and inorganic pollutants, the assessment of their combined effect is of special interest. 
It is known that changes in the composition and quantity of photosynthetic pigments are highly sensitive stress indicators in plants. The excess of HMs may induce the significant toxic effect on the photosynthetic apparatus, e.g. $\mathrm{Cu}$ ions may substitute for manganese in chlorophyll molecules in both antenna complexes and reactivation centres, thus damaging the structure and function of pigments (Tanyolac et al. 2007). The present study has shown that the high concentration of urea $(5 \mathrm{mM})$ and the studied metals $(100 \mu \mathrm{M})$ has adversely affected the pigment system of $E$. densa (Supplementary Figure). There was a strong chlorosis after 4 days of $\mathrm{Cu}$ exposure especially under the combined action of urea with $\mathrm{Cu}$. The significant loss in Chl $a$ and especially carotenoid content was also observed. It was confirmed by the significant increase in the ratio of the total chlorophyll to carotenoids. Such phenomenon (especially in the presence of urea) could probably be explained by the more powerful toxic $\mathrm{Cu}$ effects as redox-active metal ion on carotenoids, so they were destroyed faster than chlorophylls. Furthermore, similar finding has also been reported for other aquatic plants (Upadhyay and Kumar 2009; Xing et al. 2010).

The ratio of Chl $a$ to $\mathrm{Chl} b$ was reduced in all treatments, but it was found to be the maximum for the $\mathrm{Cu}$-treated plants. The reduction of this ratio was apparently due to the greater stability of $\mathrm{Chl} b$. The changes in this ratio can indicate the various disorders in the photosynthetic function of plant under the pollutant action (Tanyolac et al. 2007).

Lipid peroxidation is often considered as an indicator reaction of cell damage (Min et al. 2013). Obviously, the exposure of $E$. densa in the presence of either urea or $\mathrm{Ni}$ ions, as well as the combined effect of these pollutants caused membrane oxidation. As abiotic stressor, Ni indirectly causes the production and accumulation of ROS and thus induces lipid peroxidation. The exposure of cucumber and wheat seedling to the high level of Ni enhanced MDA content (Pandolfini et al. 1992; Khoshgoftarmanesh et al. 2014). At the same time, the level of lipid peroxidation decreased in $\mathrm{Cu}$ - and Urea $+\mathrm{Cu}$-treated plants. Probably, this treatment resulted in the degradation of lipid peroxidation products.

In response to oxidative stress, plants may activate several defense mechanisms including the synthesis of low molecular weight antioxidants such as proline and ascorbic acid. Proline provides protection by chelating HMs in the cytoplasm, scavenging ROS and reducing metals uptake (Szabados and Savouré 2010). The induction of this amino acid in plants in response to HMs is to a great extent concentration dependent, and plant and metal specific. Proline accumulation is induced under stress due to both an increase in the synthesis and a reduction in the oxidized amino acid (Ahmad et al. 2015). It was shown that under stress most of the accumulated proline was formed because of its elevated synthesis from glutamate or from arginine and ornithine (Mokronosov et al. 1966; Polacco et al. 2013). Probably, the accumulation of these intermediates during urea and Urea $+\mathrm{Ni}$ treatment may contribute to the proline synthesis. However, in spite of the urea addition, the extensive destruction of proline under $\mathrm{Cu}$ treatment was observed.

Another commonly known water-soluble antioxidant is ascorbic acid, which plays an important role in the resistance to oxidative stress. Increasing evidence indicates that ascorbate is centrally involved in several physiological processes. However, the mechanisms by which this acid reduces the damaging effects of stressors are still being discussed (Upadhyay and Kumar 2009). The present study showed the increase in ascorbic acid level under the action of all the pollutants studied. This probably indicates the important role of ascorbic acid as an antioxidant.

The protein content in tissue is an important indicator of reversible and irreversible metabolism changes, known to respond to a wide variety of stressors including HMs. The inhibition of protein metabolism was observed in aquatic macrophytes Lemna minor L. (Hou et al. 2007) and in Pistia stratiotes L. (Upadhyay and Kumar 2009) under the $\mathrm{Cu}$ stress. This was also evidenced by the sharp decrease in the amount of soluble protein in the present experiment $(\mathrm{Cu}$ and Urea $+\mathrm{Cu})$.

The stimulation effect of urea on urease activity as well as strengthening its activity with the addition of $\mathrm{Ni}$ to urea was also previously reported in rice (Gerenda et al. 1998). At the same time, urea and $\mathrm{Ni}$ are the substrate and the cofactor for this enzyme, respectively. Urease is a Ni-dependent enzyme that catalyses the reaction of hydrolytic decomposition of urea to ammonia and carbon dioxide. It is common in plants, bacteria, fungi and some invertebrates (Polacco et al. 2013). Since Ni is a part of the active site of urease, it was assumed that the addition of these ions would stimulate the enzyme activity. Nevertheless, $\mathrm{Ni}$ alone inhibited the activity of urease (Fig. 2a). However, the simultaneous addition of $\mathrm{Ni}$ and urea as a substrate required for the normal function of this enzyme sharply stimulated the activity of urease. The decreased urease activity in $\mathrm{Cu}$-treated plants confirms the high toxicity of $\mathrm{Cu}$ ions. Their toxic effect was enhanced by the addition of urea.

To mitigate the harmful effects of oxidative stress, plants also activate antioxidant enzyme system, which includes catalase, ascorbate peroxidase and guaiacol peroxidase. However, the effects of HMs on the activities of enzymes scavenging ROS remain controversial (Pandolfini et al. 1992; Yilmaz and Parlak 2011). It was reported that $\mathrm{Cu}$ ions could increase the CAT and GPX activities especially during the first 2 days of treatment (Teisseire and 
Guy 2000). We found a significant decrease in CAT activity in Brazilian elodea leaves of all the treated plants. The negative effect was stronger in the case of the studied metals, whereas the peroxidase activities (both APX and GPX) in $\mathrm{Ni}$ and especially in $\mathrm{Cu}$-treated plants were particularly increased. A significant increase in enzyme activity was observed when urea was added to $\mathrm{Cu}$. The activity of all enzymes was originally calculated for a protein that was destroyed by treatment with $\mathrm{Cu}$ and under the combined action of Urea $+\mathrm{Cu}$. Consequently, the peroxidases are more resistant to the toxic effects of this redox-active metal.

The present study indicates that the high dose of urea (5 $\mathrm{mM})$ has a significant toxic effect on physiological and biochemical characteristics of $E$. densa such as the content of Chl $a$ and activities of antioxidant enzymes (CAT, APX and GPX). An elevated level of lipid peroxidation was accompanied by the accumulation of the low molecular weight antioxidants (proline and ascorbate). Incubating plants under the presence of urea and Ni (separately and combined) resulted in the generation of oxidative stress and consequently the antioxidant system activation. The combined effect of urea with $\mathrm{Ni}$ notably increased urease activity. Urea with $\mathrm{Cu}$ adversely affected $E$. densa photosynthetic pigment system. Urease activity greatly decreased in $\mathrm{Cu}$-treated plants, especially under Urea $+\mathrm{Cu}$ treatment. The $\mathrm{Cu}$ concentration of $100 \mu \mathrm{M}$ was lethal to $E$. densa; however, peroxidases were found most resistant to the toxic effects of this redox-active metal. The study concludes that the addition of urea to HMs may enhance the toxic effects in Brazilian elodea leaves, especially in case of $\mathrm{Cu}$. Further research is required to test the impact of different concentration of other HMs (acting separately and combined) with the varieties of aquatic macrophytes.

Acknowledgments The work was supported by the grant of Russian Foundation for Basic Research (15-04-08380 A) and Act 211 Government of the Russian Federation, Agreement No. 02.A03.21.0006.

\section{Compliance with ethical standards}

Conflict of interest The authors declare that there are no conflicts of interest.

\section{References}

Aebi H (1971) Catalases. Methods Enzym Anal 3:273-286

Ahmad N, Alatar AA, Faisal M, Khan MI, Fatima N, Anis M, Hegazy AK (2015) Effect of copper and zinc on the in vitro regeneration of Rauvolfia serpentina. Biol Plant 59:11-17

Alia-Saradhi PP (1991) Proline accumulation under heavy metal stress. J Plant Physiol 138:554-558

Azizullah A, Nasir A, Richter P, Lebert M, Hader DP (2011) Evaluation of the adverse effects of two commonly used fertilizers, DAP and urea, on motility and orientation of the green flagellate Euglena gracilis. Environ Exp Bot 74:140-150

Bates LS (1973) Rapid determination of free proline for water stress studies. Plant Soil 39:205-207

Bradford MM (1976) A rapid and sensitive method for the quantitation of microgram quantities of protein utilizing the principle of protein-dye binding. Anal Biochem 72:248-254

Chance B, Maehly AC (1955) Assay catalase and peroxidase. Methods in Enzymol 2:764-775

Chukina NV, Borisova GG (2010) Structural and functional induces of higher aquatic plants from habitats differing in levels of anthropogenic impact. Inland Water Biol 3:44-50

Federal Fisheries Agency (2010) Concerning approval of water quality standards for commercial fishery water bodies, including standards for maximum permissible concentrations of harmful substances in waters of commercial fish. Order of January 18, No. 20 [in Russian]. http://gostperevod.com/orders/rf-federalfisheries-agency-order-no-20-on-january-18-2010-detail Accessed on 6 Mar 2016

Finay K, Patoine A, Donald D, Bogard MJ, Leavitt PR (2010) Experimental evidence that pollution with urea can degrade water quality in phosphorus-rich lakes of the Northern Great Plains. Limnol Oceanogr 55:1213-1230

Gerenda J, Zhu Z, Sattelmacher B (1998) Influence of $\mathrm{N}$ and $\mathrm{Ni}$ supply on nitrogen metabolism and urease activity in rice (Oryza sativa L.). J Exp Bot 49:1545-1554

Glibert PM, Harrison J, Heil C, Seitzinger S (2006) Escalating worldwide use of urea-a global change contributing to coastal eutrophication. Biogeochemistry 77:441-463

Haifang D, Yajun X, Longfei Z, Changjuan S (2016) Alleviation of copper toxicity on chloroplast antioxidant capacity and photosystem II photochemistry of wheat by hydrogen sulfide. Braz $\mathbf{J}$ Bot. doi:10.1007/s40415-016-0250-6 (In press)

Health RL, Packer L (1968) Photoperoxidation in isolated chloroplasts: I. Kinetics and stoichiometry of fatty acid peroxidation. Arch Biochem Biophys 125:189-198

Hewitt EJ, Dickes GJ (1961) Spectrophotometric measurements on ascorbic acid and their use for the estimation of ascorbic acid and dehydroascorbic acid in plant tissues. Biochem J 78:384-391

Hou W, Chen X, Song G, Wang Q, Chang C (2007) Effects of copper and cadmium on heavy metal polluted waterbody restoration by duckweed (Lemna minor). Plant Physiol Biochem 45:62-69

Jayaraman J (1981) Laboratory manual in biochemistry. Wiley, New Delhi

Kalinkina LG, Nazarenko LV, Gordeeva EE (1990) Modified method for extraction of free amino acids and their determination in amino acid analyzer. Fiziol Rast (Sov Plant Physiol) 37:617-621

Khoshgoftarmanesh AH, Bahmanziari H, Sanaeiostovar A (2014) Responses of cucumber to deficient and toxic amounts of nickel in nutrient solution containing urea as nitrogen source. Biol Plantarum 58:524-530

Krogmeier MJ, McCarty W, Bremner JM (1989) Phytotoxicity of foliar-applied urea. Proc Nation Acad Sci USA 86:8189-8191

Lichtenthaler HK (1987) Chlorophylls and carotenoids: pigments of photosynthetic membranes. Meth Enzymol 148:350-382

Maksymiec W (1997) Effect of copper on cellular processes in higher plants. Photosynthetica 34:321-342

Maleva MG, Nekrasova GF, Malec P, Prasad MNV, Strzałka K (2009) Ecophysiological tolerance of Elodea canadensis to nickel exposure. Chemosphere 77:393-398

Maleva MG, Nekrasova GF, Borisova GG, Chukina NV, Ushakova OS (2012) Effect of heavy metals on photosynthetic apparatus and antioxidant status of Elodea. Rus J Plant Physiol 59:190-197

Maleva MG, Borisova GG, Chukina NV, Nekrasova GF, Prasad MNV (2013) Influence of exogenous urea on photosynthetic pigments, 
${ }^{14} \mathrm{CO}_{2}$ uptake and urease activity in Elodea densa - environmental implications. Environ Sci Pollut Res 20:6172-6177

Maleva M, Borisova G, Chukina N, Prasad MNV (2015) Ureainduced oxidative damage in Elodea densa leaves. Environ Sci Pollut Res 22(17):13556-13563

Min HL, Cai SJ, Rui Z, Sha S, Xie KB, Xu QS (2013) Calciummediated enhancement of copper tolerance in Elodea canadensis. Biol Plantarum 57:365-369

Mokronosov AT, Ilinykh ZG, Shukolyukova NI (1966) Assimilation of urea potato plants. Fiziol Rast (Sov Plant Physiol) 13:798-806

Nakano Y, Asada K (1981) Hydrogen peroxide is scavenged by ascorbate specific peroxidase in spinach chloroplasts. Plant Cell Physiol 22:867-880

Pandolfini T, Gabbrielli R, Comparini C (1992) Nickel toxicity and peroxidase activity in seedlings of Triticum aestivum L. Plant Cell Environ 15:719-725

Polacco JC, Mazzafera P, Tezotto T (2013) Opinion-Nickel and urease in plants: still many knowledge gaps. Plant Sci 199-200:79-90

Szabados L, Savouré A (2010) Proline: a multifunctional amino acid. Trends Plant Sci 15:89-97

Tanyolac D, Ekmekci Y, Unalan A (2007) Changes in photochemical and antioxidant enzyme activities in maize (Zea mays L.) leaves exposed to excess copper. Chemosphere 67:89-98
Teisseire H, Guy V (2000) Copper-induced changes in antioxidant enzymes activities in fronds of duckweed (Lemna minor). Plant Sci 153:65-72

Upadhyay RK (2014) Metal stress in plants: its detoxification in natural environment. Braz J Bot 37:377-382

Upadhyay RK, Kumar SP (2009) Copper-induced growth inhibition, oxidative stress and ultrastructural alterations in freshly grown water lettuce (Pistia stratiotes L.). CR Biol 332:623-632

Witte CP (2011) Urea metabolism in plants. Plant Sci 180:431-438

Xing W, Huang W, Liu G (2010) Effect of excess iron and copper on physiology of aquatic plant Spirodela polyrrhiza (L.) Schleid. Environ Toxicol 25:103-112

Yadav SK (2010) Heavy metals toxicity in plants: an overview on the role of glutathione and phytochelatins in heavy metal stress tolerance of plants. South African J Bot 76:167-179

Yilmaz DD, Parlak KU (2011) Nickel-induced changes in lipid peroxidation, antioxidative enzymes, and metal accumulation in Lemna gibba. Int J Phytorem 13:805-817

Zhang JH, Guo SJ, Guo PY, Wang X (2014) The interacting effect of urea and fenoxaprop-P-ethyl on photosynthesis and chlorophyll fluorescence in Perilla frutescens. Photosynthetica 52:456-463 